\title{
Ground Temperatures under Ski Pistes with Artificial and Natural Snow
}

\author{
Christian Rixen* $+\S$ \\ Wilfried Haeberli $\ddagger$ and \\ Veronika Stoeckli* \\ *Swiss Federal Institute for Snow and \\ Avalanche Research SLF, Flüelastrasse 11, \\ 7260 Davos Dorf, Switzerland \\ $\dagger$ Institute for Environmental Sciences, \\ University of Zurich, Winterthurerstrasse \\ 190, 8057 Zürich, Switzerland. \\ ¥Department of Geography, University of \\ Zurich, Winterthurerstrasse 190, 8057 \\ Zürich, Switzerland. \\ §rixen@slf.ch
}

\begin{abstract}
Increasing production of artificial snow in ski resorts is controversially discussed, but only few investigations have been carried out systematically to specify the environmental impacts. We measured snow depth and density from groomed ski pistes (runs) with compacted snow and their effects on ground temperatures and timing of snowmelt. We analyzed groomed pistes with and without artificial snow (10 each) as well as adjacent ungroomed off-piste control plots beside the piste. On pistes with natural snow, the thin and compacted snow cover led to severe and long lasting seasonal soil frost. On pistes with artificial snow, soil frost occurred less frequently because of increased insulation due to the greater snow depth. However, due to the greater snow mass, the beginning of the snowfree season was delayed by more than $2 \mathrm{wk}$. Average winter ground temperatures under a continuous snow cover were decreased by approximately $1^{\circ} \mathrm{C}$ on both piste types compared with off-piste control plots. The results suggest that the heat balance of alpine soils is changed by both piste types, either by an extensive heat loss on pistes with natural snow or by prolonged snow cover on pistes with artificial snow.
\end{abstract}

\section{Introduction}

Producing artificial snow is becoming increasingly important for the preparation of ski pistes (runs). Almost $59 \%$ of the ski resorts in the United States produced artificial snow in 1984 (Kocak and van Gemert, 1988), in 2001 more than 90\% (Seilbahnen Schweiz, 2001). In Switzerland, $7 \%$ of all ski pistes received artificial snow in 2001, and the number is steadily increasing. It is economically insecure to rely on natural snowfall when the skiing season is supposed to start in early winter for touristic reasons (Bürki, 1998). With ongoing climatic changes, the lower limit of economically safe snow conditions for winter sport in the European Alps is assumed to rise from 1200 today to $1500 \mathrm{~m}$ a.s.l. within the next 25 to $50 \mathrm{yr}$ (Abegg et al., 1997; Elsasser and Messerli, 2001).

Extensive research has been carried out on the impacts of ski piste constructions and ski pistes in general on soil and vegetation (Grabherr, 1985; Price, 1985; Urbanska, 1990; Tsuyuzaki, 1995; Urbanska, 1995; Bayfield, 1996; Urbanska, 1997; Titus and Tsuyuzaki, 1999; Fattorini, 2001). However, the thermal aspects of a compacted snow cover on pistes and added artificial snow have only been addressed in a few studies (Haeberli, 1982, 1992; Mellini, 1996; Newesely, 1997; Stoeckli and Rixen, 2000; Rixen et al., 2001). It is well known that the density of the snow influences its thermal conductivity (Andrews, 1886; Sturm et al., 1997). However, the complex thermal interactions of snow properties like density and depth and important properties influencing the thermal regime of specific locations such as aspect, elevation, inclination, radiation etc. make it difficult to estimate the influence of an artificially changed snow cover on the soil (Jones et al., 2001, but see Funk and Hoelzle, 1992; Mittaz et al., 2000). Obviously, a deep snow cover insulates the soil well and thus prevents the soil from freezing (e.g., Auerbach and Halfpenny, 1991; Pomeroy and Brun, 2001). Under a thin snow cover, e.g. on wind-blown ridges, ground temperatures can drop to $-30^{\circ} \mathrm{C}$ (May et al., 1982). In experimental approaches, ground temperatures were increased considerably when snow depth was increased (Walker et al., 1999). On ski pistes, Newesely (1997) found indications that the increased thermal conductivity of compacted snow can cause severe frost in the soil.
When the ecological impacts of ski piste preparations and snow compaction with snow-grooming vehicles are to be assessed, it is important to understand in which way the snow cover is changed. Specific properties of artificial snow have been studied in detail by Mosimann (1987). He showed that (1) the snow profile of the artificial snow is more homogenous, (2) the ice crystals are spherical and not dendritic, (3) the melting process is slower due to the increased snow mass, and (4) the artificial snow contains more ice layers and lenses. The snow contains the more ice the warmer the conditions during snow production are, thus in general at lower elevation and southern aspect. To understand the thermal consequences for the affected ground, we primarily have to know snow density and depth. With this information it can be estimated to what extent plants and soil could be affected by a modified snow cover. A modified snow cover could change the species composition (Baiderin, 1982; Rixen et al., 2002) and soil characteristics of alpine habitats (Freppaz et al., 2002).

In our study, we address the following questions: How is the snow cover changed on groomed ski pistes with or without artificial snow compared to undisturbed snow? Do we find changed ground temperatures on ski pistes with or without artificial snow compared to undisturbed snow? To what extent is the energy budget modified on ski pistes? Given that the current knowledge about the snow cover on ski pistes is based on investigations of single pistes, our goal was to obtain information that can be generalized for the current situation in the Swiss Alps. Hence, we analyzed a larger number of representative ski resorts, which is the first such approach. Our data represent average values that hold for Switzerland with the given climate and the given practices of piste preparation. With a different climate or different snowing practices, ground temperatures, heat balances etc. are likely to deviate from our results. We discuss the possible consequences of ground temperature changes for the occurrence of permafrost and for soil and vegetation dynamics.

\section{Material and Methods}

\section{STUDY SITES}

The study plots were selected in ten ski resorts in Switzerland (Fig. 1) according the following criteria: Artificial snow should have 




FIGURE 1. Snow depth at $2000 \mathrm{~m}$ a.s.l. in Switzerland on 1 March 2000 and locations of ski resorts investigated.

been used for several years and in large amounts, and the resorts should represent the most important ski regions of Switzerland. Furthermore, various elevations, aspects, and amounts of radiation should be covered (Table 1). Due to the fact that artificial snow has been used mostly in the southern cantons Grisons and Valais, five resorts were selected in Grisons, four in Valais and one in the canton Schwyz in the Northern Alps (Table 1). The altitudinal belts considered include subalpine and alpine conditions but not subnival periglacial areas with extended permafrost occurrence.

\section{$D E S I G N$}

In each ski resort, we selected plots on a piste with artificial snow and on a piste with natural snow. Additional plots were chosen as controls beside each piste plot with similar environmental conditions such as aspect and slope. With this design, we obtained paired data with 10 replications from pistes with artificial snow on the one hand and from pistes with natural snow on the other hand $(10 \times 2 \times 2)$. The selection of the plots took place in consultation with the local ski piste managers to find appropriate locations where snow had been produced for many years.

\section{GROUND TEMPERATURES}

Miniature universal temperature loggers (UTL) were used to measure the ground temperatures continuously (Krummenacher et al., 1998; Hoelzle et al., 1999). Within a plot sized $10 \times 10 \mathrm{~m}$ of relatively homogenous ground, the location for the logger was selected randomly. We marked the locations with recco $^{\circledR}$-plates (avalanche victim detection devices) for relocation (Recco Rescue Systems, 1999). The loggers were placed in the soil with the sensor $1 \mathrm{~cm}$ below the soil surface in October 1999. They recorded the temperature with a precision of better than $0.25^{\circ} \mathrm{C}$ (Hoelzle et al., 1999) every hour during the whole measurement period. Data were captured in the field with a laptop between May and June 2000 and 2001, respectively. Missing values due to technical problems were few (approximately $10 \%$ ) in the first year and considerable (approximately 50\%) in the second year of measurements.

From the hourly recorded temperature data, we determined (1) the time of snow cover formation, defined as the first day with ground temperature fluctuation of less than $5^{\circ} \mathrm{C}$ within $24 \mathrm{~h}$ (as a measure of insulation by the snow), (2) the beginning of the snow-free season, defined as the first day with ground temperatures $>0^{\circ} \mathrm{C}$, (3) the duration of the winter snow cover, (4) the minimum temperatures under the snow cover, (5) the number of days with ground temperatures colder than $-1^{\circ} \mathrm{C}$ (temperatures below $0^{\circ} \mathrm{C}$ compared well with data on frost measured with frost tubes in a study of Hardy et al. [2001]), (6) the average ground temperature from the time of snow-cover formation in early winter until the time that the last of both loggers became free of snow (for each pair of loggers), and (7) the average ground temperature during the snow-covered period, calculated separately for each logger.

\section{SNOW COVER}

The snow characteristics of the 40 sites were investigated between 21 February and 2 March 2000. We determined the location of the

TABLE 1

Study sites. Each ski resort contained four plots: one on a piste with artificial snow plus an off-piste control plot beside the piste and one on a piste with natural snow plus an off-piste control plot. Site characteristics are shown for each pair of plots (piste and off-piste control). Cantons: SZ $=$ Schwyz, GR=Grisons, VS =Valais. AS=artificial snow, NS=natural snow. The potential radiation was calculated after Funk and Hoelzle (1992)

\begin{tabular}{|c|c|c|c|c|c|c|c|}
\hline Ski resort & $\begin{array}{l}\text { Elevation } \\
\text { (m a.s.l.) }\end{array}$ & Aspect & Slope $\left({ }^{\circ}\right)$ & $\begin{array}{c}\text { Artificial } \\
\text { snow since }\end{array}$ & $\begin{array}{l}\text { Degree of } \\
\text { latitude }\end{array}$ & $\begin{array}{l}\text { Degree of } \\
\text { longitude }\end{array}$ & $\begin{array}{l}\text { Potential radiaton } \\
\qquad\left(\mathrm{MJ} \mathrm{m}^{-2} \mathrm{~d}^{-1}\right)\end{array}$ \\
\hline Alptal (SZ), AS & 1150 & SE & $0-5$ & 1997 & $47^{\circ} 02^{\prime} 44 \mathrm{~N}$ & $8^{\circ} 42^{\prime} 08 \mathrm{E}$ & 18.725 \\
\hline Alptal (SZ), NS & 1180 & $\mathrm{~W}$ & $5-10$ & - & $47^{\circ} 02^{\prime} 30 \mathrm{~N}$ & $8^{\circ} 42^{\prime} 53 \mathrm{E}$ & 17.723 \\
\hline Morgins (VS), AS & 1720 & ESE & 25 & 1997 & $46^{\circ} 13^{\prime} 23 \mathrm{~N}$ & $6^{\circ} 51^{\prime} 36 \mathrm{E}$ & 19.656 \\
\hline Morgins (VS), NS & 1735 & ESE & 10 & - & $46^{\circ} 13^{\prime} 07 \mathrm{~N}$ & $6^{\circ} 51^{\prime} 34 \mathrm{E}$ & 19.452 \\
\hline Nendaz (VS), AS & 1765 & $\mathrm{~N}$ & 20 & 1992 & $46^{\circ} 10^{\prime} 14 \mathrm{~N}$ & $7^{\circ} 17^{\prime} 40 \mathrm{E}$ & 15.256 \\
\hline Nendaz (VS), NS & 2000 & SW & 24 & - & $46^{\circ} 09^{\prime} 21 \mathrm{~N}$ & $7^{\circ} 16^{\prime} 55 \mathrm{E}$ & 22.179 \\
\hline Montana (VS), AS & 1935 & SSE & 15 & $1995 / 97$ & $46^{\circ} 19^{\prime} 29 \mathrm{~N}$ & $7^{\circ} 28^{\prime} 47 \mathrm{E}$ & 24.483 \\
\hline Montana (VS), NS & 1940 & $\mathrm{~S}$ & 24 & - & $46^{\circ} 19^{\prime} 29 \mathrm{~N}$ & $7^{\circ} 28^{\prime} 42 \mathrm{E}$ & 24.699 \\
\hline Lenzerheide (GR), AS & 1970 & $\mathrm{~W}$ & 15 & 1989 & $46^{\circ} 44^{\prime} 33 \mathrm{~N}$ & $9^{\circ} 34^{\prime} 33 \mathrm{E}$ & 9.116 \\
\hline Lenzerheide (GR), NS & 1995 & SW & 20 & - & $46^{\circ} 45^{\prime} 10 \mathrm{~N}$ & $9^{\circ} 34^{\prime} 45 \mathrm{E}$ & 9.116 \\
\hline Davos (Jakobsh., GR), AS & 2205 & $\mathrm{~W}$ & 22 & 1993 & $46^{\circ} 46^{\prime} 26 \mathrm{~N}$ & $9^{\circ} 50^{\prime} 13 \mathrm{E}$ & 17.009 \\
\hline Davos (Jakobsh., GR), NS & 2130 & $\mathrm{~W}$ & 6 & - & $46^{\circ} 46^{\prime} 28 \mathrm{~N}$ & $9^{\circ} 49^{\prime} 59 \mathrm{E}$ & 18.763 \\
\hline Laax (GR), AS & 2170 & SSW & 8 & 1995 & $46^{\circ} 49^{\prime} 49 \mathrm{~N}$ & $9^{\circ} 12^{\prime} 44 \mathrm{E}$ & 23.680 \\
\hline Laax (GR), NS & 2125 & SE & 23 & - & $46^{\circ} 50^{\prime} 38 \mathrm{~N}$ & $9^{\circ} 10^{\prime} 48 \mathrm{E}$ & 13.776 \\
\hline Scuol (GR), AS & 2350 & ESE & 11 & 1989 & $46^{\circ} 48^{\prime} 51 \mathrm{~N}$ & $10^{\circ} 16^{\prime} 04 \mathrm{E}$ & 20.426 \\
\hline Scuol (GR), NS & 2335 & ENE & 9 & - & $46^{\circ} 48^{\prime} 46 \mathrm{~N}$ & $10^{\circ} 16^{\prime} 02 \mathrm{E}$ & 21.967 \\
\hline St. Moritz (Corv., GR), AS & 2340 & NW & 14 & 1985 & $46^{\circ} 26^{\prime} 11 \mathrm{~N}$ & $9^{\circ} 48^{\prime} 54 \mathrm{E}$ & 14.604 \\
\hline St. Moritz (Corv., GR), NS & 2510 & NNW & 20 & - & $46^{\circ} 25^{\prime} 53 \mathrm{~N}$ & $9^{\circ} 49^{\prime} 02 \mathrm{E}$ & 13.138 \\
\hline Zermatt (VS), AS & 2515 & NNE & 15 & 1985 & $45^{\circ} 59^{\prime} 08 \mathrm{~N}$ & $7^{\circ} 42^{\prime} 52 \mathrm{E}$ & 17.085 \\
\hline Zermatt (VS), NS & 2400 & $\mathrm{NE}$ & 5 & - & $45^{\circ} 59^{\prime} 29 \mathrm{~N}$ & $7^{\circ} 42^{\prime} 12 \mathrm{E}$ & 14.080 \\
\hline
\end{tabular}



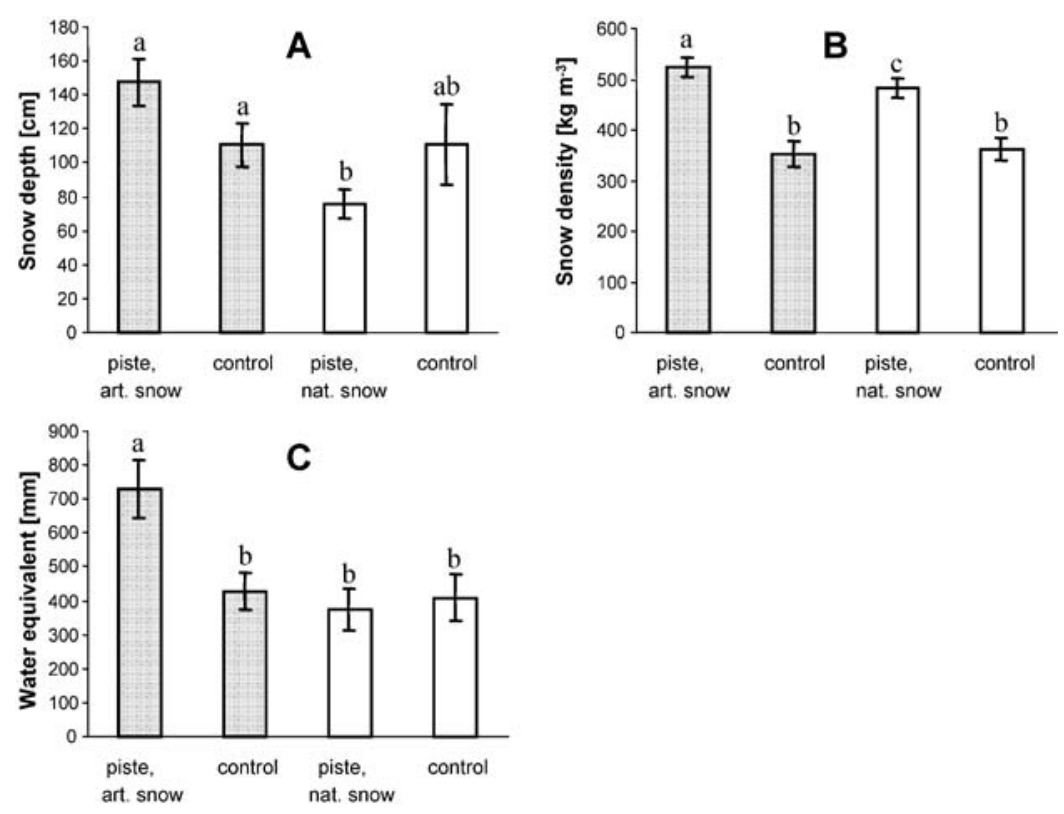

FIGURE 2. Snow depth (A), density $(B)$, and water equivalent $(C)$ in the winter 1999/2000 (mean and standard error of means). The shaded bars indicate the pistes with artificial snow and their offpiste control plots beside the piste; the unshaded bars indicate the pistes with natural snow and their off-piste control plots. Different letters above bars indicate significant differences $(\mathrm{P}<0.05)$ according to Wilcoxon signed-rank tests. The difference between snow depth of piste, artificial snow, and offpiste control is marginally significant, as is the difference between piste, natural snow, and control. logger under the snow cover with a recco-detector responding to the recco-plate on the logger. The snow cover was investigated at least 50 $\mathrm{cm}$ beside the temperature logger in order to determine snow cover characteristics close to the loggers but without disturbing the temperature measurements. We sampled the snow with a SIPRE (for Snow, Ice, Permafrost Research Establishment) corer (diameter $8 \mathrm{~cm}$ ) (Horner, 1990). The complete snow core was subdivided into $30-\mathrm{cm}$ pieces of which the weight was measured with a spring balance in the field. The length of the complete snow core displayed the total depth of the snow cover. The water equivalent was calculated as a product of snow depth and density.

To demonstrate heat transfer through the types of snow cover we measured, we calculated the effective conductivity $k_{\text {eff }}$ of the snow cover in relation the snow depth $\Delta Z$, based on the following theory: Heat transfer through the snow can be described by $q=k \Delta T / \Delta Z$ where $\Delta Z$ and $\Delta T$ are snow depth and temperature difference across the snowpack, and the effective conductivity $k=0.138-1.01 \rho+3.233 \rho^{2}$ (where $\rho$ is density, Sturm et al., 1997). By calculating $k / \Delta Z$, we can show the relative controls of $\Delta Z$ and $\rho$ on the insulation of the snowpack (Fig. 2). Based on $q=k \Delta T / \Delta Z$ and $q$ and $T_{\text {snow surface }}$ being equal, we further calculated $\Delta T_{\text {piste }} / \Delta T_{\text {control }}$ and $\Delta T_{\text {piste nat. snow }}$ $\Delta T_{\text {piste art. snow }}$ as an estimate for subnivean soil cooling.

The snow cover in Switzerland in the winter 1999/2000 was average or above average in most parts of the country including our research sites (Data base, SLF) with snow above average in the northern Swiss Alps and below average in some southern parts. Thus, we can assume that our snow measurements are about representative to slightly above average. The amounts of artificial snow are similar each year as the production of snow usually starts in November and stops in February.

\section{STATISTICAL ANALYSIS}

The data were analyzed with a mixed model ANOVA (analysis of variance, Green and Tukey, 1960), a powerful parametric procedure to analyze complex statistical designs. The factors "elevation" and "resort" were included as covariates in the analysis of the data from $1 \mathrm{yr}$ and, additionally, the factor "year" for the data of $2 \mathrm{yr}$. "Elevation" explained better than the other environmental covariates "aspect" or "slope" the differences between sites so that the latter were not included in the model. Because "resort" was regarded as a random factor, the snow type and piste/control were tested against their interactions with "resort." To mirror the study design with pairs of plots on and next to pistes, we fitted the type of plot pairs, i.e. the type of piste treatment of the piste plot in the pair. Hence, the interactions snow-by-piste display differences between the relation "piste with artificial snow" and "control" versus "piste with natural snow" and "control." Transformations of the data to meet the assumptions of ANOVA were not necessary. Additionally to ANOVA, Wilcoxon signed-rank tests, a standard nonparametric posthoc procedure (SPSS, 1999), were carried out in order to test pairwise differences between piste loggers and their off-piste control counterparts.

\section{Results}

\section{SNOW CHARACTERISTICS}

The snow properties met well what we had expected under the given snow treatments on the pistes. They were intuitively plausible, however, the basis for all further results. The snow depth was significantly different between the two piste types (Interaction snowby-piste: $F_{1,40}=5.797, P<0.05$, Table 2 , Wilcoxon signed-rank: $P=$ $0.005)$. On the pistes with artificial snow, the snow depth was increased due to the added snow mass despite compaction, whereas it was decreased on the pistes with natural snow due to the snow compaction compared with the off-piste control plots (Fig. 2). The difference in snow depth between the pistes with natural snow and those with artificial snow was approximately $70 \mathrm{~cm}$, with larger differences at low than at high elevations. The density of the snow cover was clearly increased on both piste types, especially in the artificial snow (Fig. 2). The water equivalent of the snow showed that the snow mass of all plot types was similar apart from that on pistes with artificial snow. There, the water equivalent was almost two times higher than on all other plots (Wilcoxon signed-rank: $P<0.03$ ). The elevation of the sites sampled had a highly significant effect on the snow density and a marginally significant effect on the water equivalent but no effect on the snow depth (Table 2, Fig. 4). The relation between snow density and plot elevation was inversely proportional.

The values of $k / \Delta Z$ show the relative controls of $\Delta Z$ and $\rho$ on the insulation of the snowpack (Fig. 3). Both piste types, especially with natural snow, showed higher values than the off-piste controls revealing an increased heat transfer due to the snow compaction on 
TABLE 2

Analysis of variance for the snow characteristics depth, density and water equivalent. The following sources of variation are included: Elevation $=$ elevation of plots, Resort $=$ ski resort, Type of plot pair $=$ Pair of pisteloff-piste control plot (artificial or natural snow), Piste $=$ piste or offpiste. $(*)$ : $\mathrm{P}<0.1$, *: $\mathrm{P}<0.05$, **: $\mathrm{P}<0.01$, ***: $\mathrm{P}<0.001, d f=$ degrees of freedom, ms $=$ mean squares, $\mathrm{F}=\mathrm{F}$-value

\begin{tabular}{|c|c|c|c|c|c|c|c|c|c|}
\hline \multirow[b]{2}{*}{ Source } & \multicolumn{3}{|c|}{ Snow depth } & \multicolumn{3}{|c|}{ Snow density } & \multicolumn{3}{|c|}{ Water equivalent } \\
\hline & df & $\mathrm{ms}$ & $F$ & $\mathrm{df}$ & $\mathrm{ms}$ & $F$ & $\mathrm{df}$ & $\mathrm{ms}$ & $F$ \\
\hline Elevation & 1 & 175.4 & 0.111 & 1 & 56682 & $28.527 * * *$ & 1 & 78251 & $3.488(*)$ \\
\hline Resort & 9 & 4038.3 & $2.564(*)$ & 9 & 10194 & $5.131^{*}$ & 9 & 73445 & $3.274(*)$ \\
\hline Type of plot pair & 1 & 7301.8 & 2.511 & 1 & 1390 & 0.176 & 1 & 294574 & $5.678^{*}$ \\
\hline Piste & 1 & 15.4 & 0.011 & 1 & 148980 & $35.743 * * *$ & 1 & 176624 & $4.967(*)$ \\
\hline Snow*Piste & 1 & 9131.0 & $5.797^{*}$ & 1 & 3577 & 1.801 & 1 & 281215 & $12.534 * *$ \\
\hline Resort*Snow & 9 & 2908.3 & 1.846 & 9 & 7881 & $3.967 *$ & 9 & 51877 & 2.312 \\
\hline Resort*Piste & 9 & 1435.1 & 0.911 & 9 & 4168 & 2.098 & 9 & 35559 & 1.585 \\
\hline Error & 8 & 1575.1 & & 8 & 1986 & & 8 & 22436 & \\
\hline Total & 40 & & & 40 & & & 40 & & \\
\hline
\end{tabular}

the pistes. The calculations for $\Delta T_{\text {piste }} / \Delta T_{\text {control }}$ resulted in values of 2.0 for artificial snow and 3.0 for natural snow showing the higher potential for soil cooling under natural snow pistes. The value for $\Delta T_{\text {piste nat. snow }} / \Delta T_{\text {piste art. snow }}$ was 1.6 .

\section{GROUND TEMPERATURES}

The lowest ground temperatures under snow occurred on the ski pistes with natural snow with an average of $-7.2^{\circ} \mathrm{C}$ in the ten ski resorts and lowest values of $-12^{\circ} \mathrm{C}$ in Zermatt and St. Moritz (Table 3, Fig. 4). Ground temperatures of less than $-3^{\circ} \mathrm{C}$ mainly occurred at elevations around and higher than $2000 \mathrm{~m}$ a.s.l. (Fig. 4). At plots on pistes with artificial snow and at all off-piste control plots, soil frost also occurred occasionally but not as severe and long-lasting as on the pistes with natural snow. The temperatures under the artificial snow were similarly balanced in terms of temperature variation and minima as those measured under uncompacted snow. In parallel with the absolute minima, the number of frost days was also highest under the pistes with natural snow (Interaction snow-by-piste: $F_{1,37}=11.926, P=0.014$, Wilcoxon signed-rank: $P<0.05$ ). There, the frost days numbered on

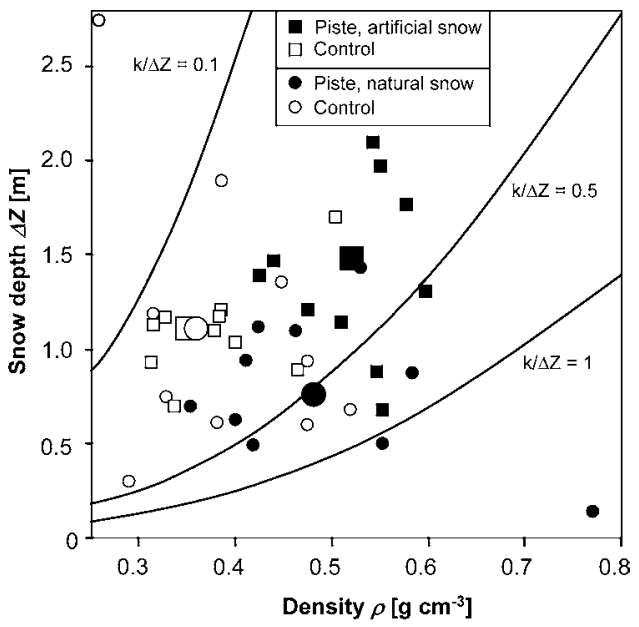

FIGURE 3. Results of the effective conductivity ( $\mathrm{k}$ ) divided by the snow depth difference $(\Delta \mathrm{Z})$ mapped on a plot of the snow depth difference $(\Delta \mathrm{Z})$ against the snow density $(\rho)$ based on the formula for the effective conductivity $\mathrm{k}=0.138-1.01 \rho+3.233 \rho^{2}$ (Sturm et al., 1997). The values of $\mathrm{k} / \Delta \mathrm{Z}$ show the relative controls of $\Delta \mathrm{Z}$ and $\rho$ on the insulation of the snowpack (the higher $\mathrm{k} / \Delta \mathrm{Z}$ the higher the insulation). The large symbols represent the mean values for the given treatments (Artificial snow, piste: 0.34. Off-piste control: 0.17. Natural snow, piste: 0.53. Off-piste control 0.18). average 55; the soils in almost all resorts above $2000 \mathrm{~m}$ a.s.l. were at least slightly frozen for a duration of 2 to $3 \mathrm{mo}$. The onset of snowmelt caused a rise in temperature to exactly $0^{\circ} \mathrm{C}$ (so-called zero curtain) until the last snow had disappeared. The disappearance of the snow cover was indicated by an immediate rise in ground temperature above $0^{\circ} \mathrm{C}$ (see Fig. 5).

In 2000, the beginning of the snowfree season was delayed by 17 $\mathrm{d}$ on average on the ski pistes with artificial snow compared to their off-piste control plots (Wilcoxon signed-rank: $P<0.02$ ). The largest difference ( $32 \mathrm{~d}$ ) between a piste with artificial snow and the off-piste control plot was found in Zermatt where the snow melted away on the piste as late as 10 June. Hardly any difference in the beginning of the snowfree season resulted between the pistes with natural snow and their off-piste control plots $(P=0.36)$. The time when the winter snow cover formed was the beginning of November in both years at most sites. The pistes with artificial snow were not covered with snow earlier than the sites with natural snow. Thus, differences in the duration of the snow cover were mainly caused by the delayed beginning of the snowfree season. In spring/summer 2001, the first snow-free day was generally later, but the differences between the snow types were the same as in the previous year. The beginning of the snow-free season on the pistes with artificial snow was again postponed by $17 \mathrm{~d}(P<0.1)$.

The average ground temperature under the continuous snow cover, calculated for each logger separately, was less than $-2^{\circ} \mathrm{C}$ under the pistes with natural snow but not less than $-0.7^{\circ} \mathrm{C}$ under artificial snow and all off-piste control plots (Table 3). Below the pistes with artificial snow, it was on average $0.5^{\circ} \mathrm{C}$ colder than below the off-piste control plots.

To evaluate the heat balance of the ground, it has to be considered that the artificial snow pistes receive less solar radiation in spring when they are still covered with snow while other areas are already snow free. This is taken into consideration when the average winter ground temperatures are calculated until the last of two loggers was snow free. Following this approach, the average ground temperatures were approximately $1.2^{\circ} \mathrm{C}$ colder under both piste types than at their adjacent off-piste control plots. Calculating temperature averages the same way for the winter 2000/2001, the difference between pistes with artificial snow and their off-piste control plots was even larger than the difference between pistes with natural snow and their control plots $(\Delta t$ $1.2^{\circ} \mathrm{C}$ vs. $0.5^{\circ} \mathrm{C}$ ). Consequently, the heat balance was similarly or even more decreased on pistes with artificial snow than on pistes with natural snow.

\section{Discussion}

The purpose of this study was to investigate how the winter environment and temperature characteristics of ski pistes are influenced 
TABLE 3

Ground temperature characteristics in the winter 1999/2000 (averages of the ten ski resorts \pm standard error of means). Minimum temperature is shown for the snow-covered period. Mean winter ground temperatures are shown (1) calculated for the snow-covered period of each logger separately and (2) calculated for snow-covered period for each pair of loggers (thus positive values are possible, e.g., when a logger on an artificial snow piste is covered with snow for a long time while the off-piste control logger is already free of snow and receives solar radiation)

\begin{tabular}{|c|c|c|c|c|}
\hline & Minimum temp. $\left({ }^{\circ} \mathrm{C}\right)$ & First snow-free day & $\begin{array}{c}\text { Mean soil temp., each } \\
\text { logger snow-covered }\left({ }^{\circ} \mathrm{C}\right)\end{array}$ & $\begin{array}{l}\text { Mean soil temp., pair of } \\
\text { loggers snow-covered }\left({ }^{\circ} \mathrm{C}\right)\end{array}$ \\
\hline Ski slope (art. snow) & $-2.3( \pm 0.7)$ & 21 May $00( \pm 5 d)$ & $-0.60( \pm 0.36)$ & $-0.59( \pm 0.37)$ \\
\hline Control (art. snow) & $-3.3( \pm 1.6)$ & 4 May $00( \pm 3 d)$ & $-0.10( \pm 0.10)$ & $0.59( \pm 0.26)$ \\
\hline Ski slope (nat. snow) & $-7.2( \pm 1.2)$ & 10 May $00( \pm 7$ d) & $-2.04( \pm 0.61)$ & $-1.79( \pm 0.60)$ \\
\hline Control (nat. snow) & $-4.8( \pm 1.9)$ & 11 May $00( \pm 5 d)$ & $-0.66( \pm 0.32)$ & $-0.63( \pm 0.31)$ \\
\hline
\end{tabular}

by snow preparation and the production of artificial snow. The snow analysis clearly showed the expected increased snow density induced by the piste preparation and an increase in snow depth due to the snow production. Snow depth and density are the crucial factors that influence heat transfer as the $k / \Delta Z$ values from our plots showed. The ground temperatures confirmed that the combination of increasing snow depth and decreasing snow density on the pistes with natural snow led to heat loss and soil frost. Although artificial snow had an even higher density than compacted natural snow, its insulating properties were better due to the increased snow depth. On the other hand, the beginning of the snow-free season was postponed by more than 2 wk due to the additional snow mass. Thus, overall average ground temperatures were decreased on both piste types compared with unprepared natural snow.

\section{SNOW AND THE HEAT BALANCE OF ALPINE SOILS}

How relevant are these changes for the heat balance of an alpine soil? The average duration of the permanent snow cover in our investigation was more than half a year. Hence, a temperature difference of $1{ }^{\circ} \mathrm{C}$ during the snow-covered period means a considerable overall cooling of the ground. At an alpine site where the mean ground temperature is close to $0^{\circ} \mathrm{C}$, the additional temperature reduction may be crucial to induce permafrost. Two of our study sites are within the zone of potential permafrost: Haeberli (1975) stated that permafrost is probable at some plots in St. Moritz (above $2400 \mathrm{~m}$ a.s.l., NW) and possible in Zermatt (above $2400 \mathrm{~m}$ a.s.l., NE). Zones of likely permafrost range in the Swiss Alps between $2400 \mathrm{~m}$ a.s.l. (aspect northwest) and $3000 \mathrm{~m}$ a.s.l. (aspect south) at slopes between 5 and $10^{\circ}$ (Haeberli, 1975). The occurrence of permafrost is complex and depends on many factors such as aspect and inclination. However, at permafrost transition zones the snow properties can be an important factor contributing to the formation of permafrost (Mackay and MacKay, 1975; Goodrich, 1982; Keller and Gubler, 1993). Experimentally increased snow depth can enhance ground cooling as has been shown at arctic experimental sites (Hinkel et al., 2003; Seppälä, 2003). Interestingly, the ground temperatures on pistes with natural snow showed parallel characteristics to those from permafrost sites (Haeberli, 1973; 1992; Mellini, 1996). On permafrost soils, Haeberli (1973) found that the BTS (bottom temperature of the winter snow cover) in February and March under snow more than $0.8 \mathrm{~m}$ deep is an excellent indicator for the occurrence of permafrost. The BTS is above $-2^{\circ} \mathrm{C}$ if permafrost is unlikely, while the permafrost usually keeps the BTS below $-3^{\circ} \mathrm{C}$. Although basal snow temperatures on ski pistes with natural snow are also very low, the cause, mainly the insufficiently insulating snow cover, is very different from those in permafrost soils, which is well illustrated by the intense temperature fluctuations on ski pistes. The cooling on the natural snow pistes may even be intensified by enhanced heat loss through a thin and insufficiently insulating snow cover (Keller, 2003). Keller suggests that the heat loss of a soil under a very thin snow cover is higher than that of a snow-free soil. In the weakly insulating snow cover of a natural snow piste, this effect may last for several months or even throughout the whole winter (Mellini, 1996). However, while the described effects are likely on pistes with natural snow, heat loss also occurs on pistes with artificial snow because of the decreased solar radiation due to the delayed beginning of the snow-free season. Hence, we found that the average winter temperatures were decreased in the ground of all piste types.

Further investigations into changes of the thermal regime of ski pistes may focus on the transition zone between altitudes and aspects with likely and unlikely permafrost. It still has to be proved if

TABLE 4

Analysis of variance for ground temperature characteristics and first snowfree day in the winters 1999/2000 and 2000/2001 (for sources of variation see Table 2). Mean ground temperatures are values during the snow-covered period from snow formation until snow had disappeared at both of the two loggers of a pair. (*): $\mathrm{P}<0.1$, *: $\mathrm{P}<0.05$, **: $\mathrm{P}<0.01$, ***: $\mathrm{P}<0.001$

\begin{tabular}{|c|c|c|c|c|c|c|c|c|c|}
\hline \multirow[b]{2}{*}{ Source } & \multicolumn{3}{|c|}{ Minimum temperature } & \multicolumn{3}{|c|}{ First snowfree day } & \multicolumn{3}{|c|}{ Mean soil temp., pair of loggers snow-covered } \\
\hline & df & $\mathrm{ms}$ & $F$ & df & $\mathrm{ms}$ & $F$ & df & $\mathrm{ms}$ & $F$ \\
\hline Year & 1 & 49.51 & $21.41 * * *$ & 1 & 1419.60 & $9.871^{* *}$ & 1 & 3.58 & $5.91^{*}$ \\
\hline Elevation & 1 & 119.68 & $51.76^{* * *}$ & 1 & 3309.26 & $23.011 * * *$ & 1 & 21.57 & $35.65 * * *$ \\
\hline Resort & 9 & 19.78 & $8.56^{* * *}$ & 9 & 622.18 & $4.326^{* *}$ & 9 & 1.93 & $3.18^{*}$ \\
\hline Type of plot pair & 1 & 45.71 & 10.49 & 1 & 0.36 & 0.001 & 1 & 8.42 & $17.29 * *$ \\
\hline Piste & 1 & 42.20 & $10.30^{*}$ & 1 & 882.49 & $6.952^{*}$ & 1 & 12.57 & $29.37 * * *$ \\
\hline Snow*Piste & 1 & 12.29 & $5.31 *$ & 1 & 1845.70 & $12.834 * *$ & 1 & 0.02 & 0.03 \\
\hline Resort*Snow & 8 & 4.36 & 1.88 & 9 & 452.64 & $3.147^{*}$ & 8 & 0.49 & 0.80 \\
\hline Resort*Piste & 9 & 4.10 & 1.77 & 9 & 126.93 & 0.883 & 9 & 0.43 & 0.71 \\
\hline Error & 27 & 2.31 & & 23 & 143.81 & & 20 & 0.60 & \\
\hline Total & 59 & & & 56 & & & 52 & & \\
\hline
\end{tabular}



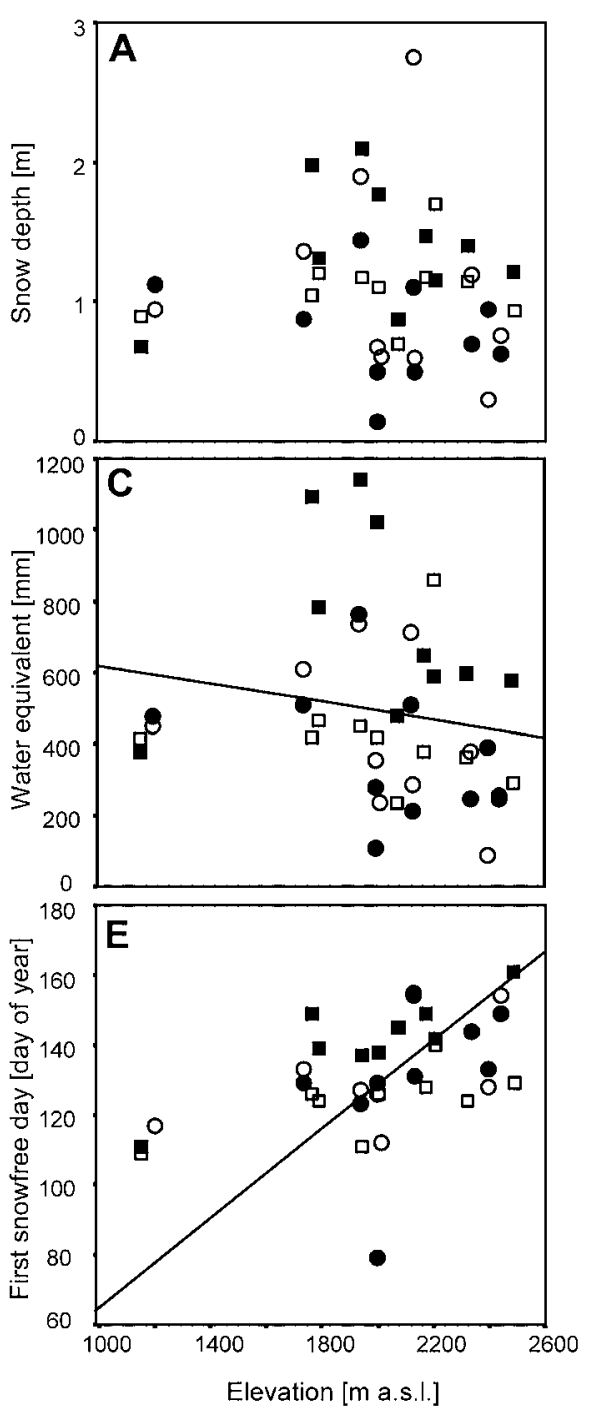
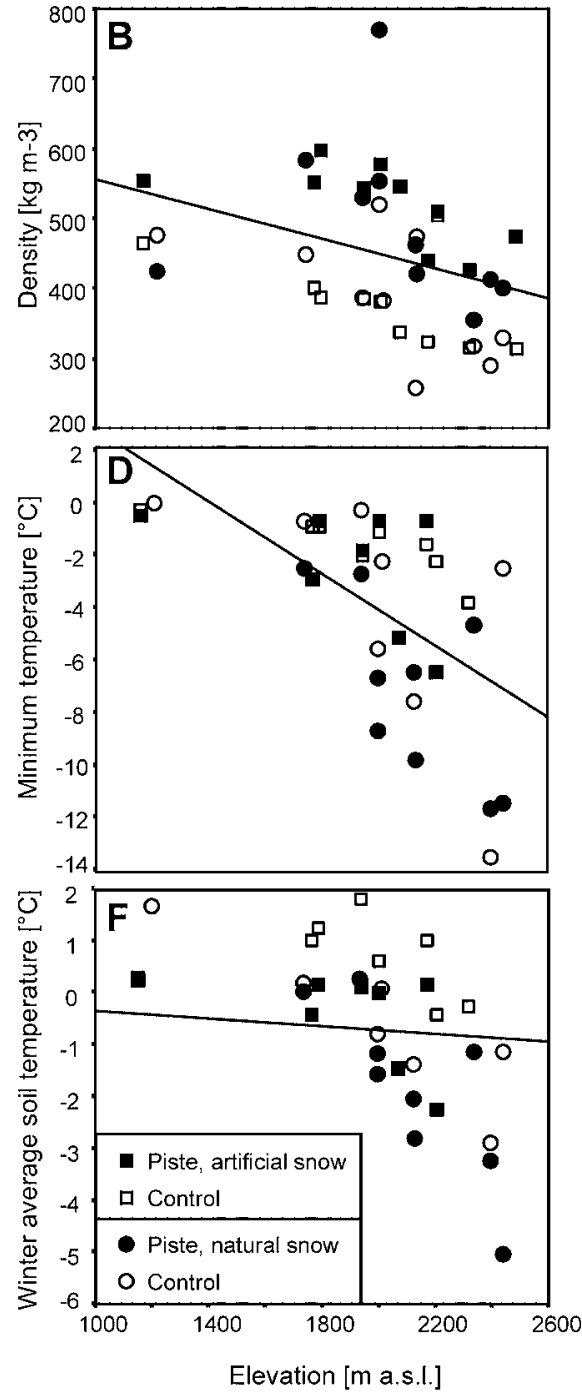

FIGURE 4. Relation between elevation, snow, and ground temperature characteristics in the winter 1999/2000: snow depth $(A)$, snow density (B), water equivalent $(C)$, minimum temperature $(D)$, first snow-free day $(E)$, winter average ground temperature (calculated for snow-covered period for each pair of loggers. Thus positive values are possible e.g. when a logger on an artificial snow piste is covered with snow for a long time while the off-piste control logger is already free of snow and receives solar radiation) $(F)$. Elevation has a highly significant influence on snow density, minimum temperature, first snowfree day, winter average ground temperature and a marginally significant influence on water equivalent (see regression lines). permafrost can be introduced by ski piste preparation. This, however, can not easily be estimated by measuring of the basal snow temperatures because they are characterized by large fluctuations. Bore holes and refraction-seismic measurements would be necessary in such an investigation.

\section{ECOLOGICAL IMPACTS OF A CHANGED WINTER ENVIRONMENT FOR PLANTS AND SOIL}

The changed snow cover and thermal regime that we found on the ski pistes may considerably influence the vegetation of the pistes as winter snow conditions are a crucial environmental factor in alpine and arctic habitats (Jones et al., 2001). The potential effects of artificial snow and natural snow on pistes on the environment have to be discussed separately. Under artificial snow, as ground temperatures are only slightly changed, the delayed beginning of the snow-free season is likely to be the most important factor influencing plant growth. Wipf et al. (in press) found indicator species for snowbeds (alpine depressions with a long-lasting snow cover [Ellenberg, 1988; Körner, 1999]) to be more frequent on pistes with artificial snow compared to off-piste control plots. This finding is in line with other studies where snow-covered time was experimentally extended: A delay in the start of the growing season due to an artificially increased snow cover caused extensive dying of Kobresia myosuroides, a species that is adapted to thin winter snow cover (Bell and Bliss, 1979; Walker et al., 1999). In a snow-manipulation experiment at a snowbed site, the snowbed specialist Sibbaldia procumbens responded in cover to late snowmelt according to its historical snow depth gradient (Galen and Stanton, 1995).

Furthermore, the increased snow depth on the artificial snow pistes may be a mechanical protection of plants from skiers and snowgrooming vehicles due to the increased snow depth (Cernusca et al., 1990): Species sensitive to mechanical disturbance, i.e. dwarf shrubs, were more common on ski pistes with artificial snow than on other pistes (Rixen, 2002; Rixen et al., 2004).

The effects of the compacted natural snow are different from those of artificial snow because only the winter environment is affected but not necessarily the length of the vegetation period. Baiderin (1982) investigated the vegetation composition on ski pistes with natural snow and found a decreasing abundance of early flowering species due to perturbed subnivean development. Wipf et al. (unpublished) found that indicator species for a shallow winter snow cover and early-flowering species were more frequent on pistes with natural snow than on off-piste control plots and on piste with artificial snow. The increased frequency and intensity of soil frost could harm plants that are not adapted to winter ground temperatures below $0^{\circ} \mathrm{C}$ and/or depend on an earlyseasonal development (Larcher, 1995). Further evidence for damage by soil frost due to decreased insulation of the snow cover was found in some recent winter snow removal experiments: Fine-root mortality of 


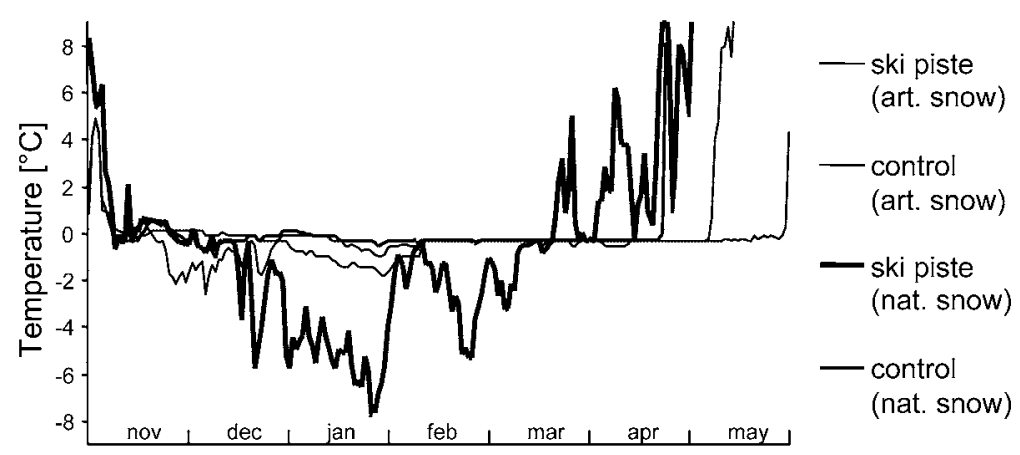

FIGURE 5. Daily mean ground temperatures in the ski resort of Nendaz between November 1999 and May 2000. Nendaz can be considered as representative for average values found in all the resorts (apart from snow disappearing early on piste with natural snow). The onset of snow cover was similar at all plots. Lowest ground temperatures and greatest temperature fluctuations occurred under pistes with natural snow. Beginning of the snowfree season was delayed on pistes with artificial snow. boreal trees was increased more likely due to mechanical damage in frozen soil than due to actual frost damage (Tierney et al., 2001; see also Weih and Karlsson, 2002). Furthermore, the duration of soil frost could influence plant water uptake, which may be limited in frozen soils (Körner, 1999). Thus, there is some evidence that induced soil frost due to decreased insulation of the snow-cover effects subnivean plants. Furthermore, the mechanical impact on the soil surface by skiers and snow-grooming vehicles is likely to be higher than on pistes with artificial snow (Rixen et al., 2002; Rixen et al., 2004).

Biogeochemical processes in the soil are considerably affected by a changed snow cover. An experimentally increased snow depth lead to an increase in subnivean $\mathrm{CO}_{2}$ and $\mathrm{N}_{2} \mathrm{O}$ production and denitrification (Williams et al., 1998) and to increased $\mathrm{N}$ mineralization (Schimel et al., 2004).

Winter soil frost due to experimental snow removal had considerable impacts on soil biogeochemistry in a study of Groffman et al. (2001). Mild soil frost increased soil nitrate $\left(\mathrm{NO}_{3}{ }^{-}\right)$concentrations in sugar maple stands. Those authors found that physical disruption due to soil freezing increased fine-root mortality and reduced plant nitrogen uptake, which allowed soil $\mathrm{NO}_{3}{ }^{-}$levels to increase even without increase in net mineralization or nitrification. Frost-induced freeze-thaw cycles can alter soil aggregate stability (Freppaz et al., 2002), carbon cycling (Neilson et al., 2001), influence $\mathrm{N}$ mineralization (Sulkava and Huhta, 2003), or plant-microbe competition for soil nitrogen (Lipson and Monson 1998). Therefore, differences in snow duration, depth, and extent may produce large changes in the $\mathrm{C}$ and $\mathrm{N}$ soil dynamics of alpine ecosystems.

The compacted snow cover on ski pistes decreases gas permeability (Newesely et al., 1994; Kammer, 2002). The decrease in gas permeability is due to ice layers that are characteristic for ski piste snow (Mosimann, 1987). As soil respiration under the snow is possible even close to $0^{\circ} \mathrm{C}$ (Sommerfeld et al., 1993; Brooks et al., 1996), the subnivean air can be enriched in $\mathrm{CO}_{2}$ (by up to $10 \%$ of the total air) and depleted in $\mathrm{O}_{2}$ (down to 5\% total) (Newesely, 1997) which makes plants more susceptible to frost damage (Newesely et al., 1994).

Both piste types can be evaluated similarly in terms of soil erosion and hydrology. Both piste types help cooling the ground and may, in the long run, change the pistes into slopes of coarse debris (Haeberli, 1992) with considerably increased erosion problems. If permafrost is induced on a ski piste, feedback mechanisms like increased lateral runoff (Kokelj and Lewkowicz, 1998) can further enhance erosion. For plants, an introduction of permafrost means a reduction in water supply, as the rooting zone is restricted to the active layer, decreased growth performance due to lower ground temperatures and a decreased soil stability. The late melting of the artificial snow can additionally increase the erosion risk in the warm season. Apart from snow-derived changes in temperature and hydrology, the ground surface of ski pistes is often being leveled or large rocks are removed to mitigate snow deficiencies in early winter. Those measures result in a disturbance of soil horizons that usually have developed over a long time period and in a strong thermal disturbance both increasing the erosion risk. Especially in high alpine permafrost regions, removal of large rocks may severely disturb the thermal characteristics of a soil. Mosimann (1985) determined zones in the central Swiss Alps where re-establishment of the vegetation hardly ever occurs after ski piste construction (above $2200 \mathrm{~m}$ a.s.l.) and where microclimatic differences cause a great variation in the success of revegetation (1600-2200 m a.s.1.). Especially in these critical zones, disturbances and erosion risk have to be considered in the management of ski piste. Although most alpine areas are not skied on, pistes cover the considerable area of $220 \mathrm{~km}^{2}$ of the Swiss Alps, which is $0.8 \%$ (Seilbahnen Schweiz, 2001) and 25\% greater than the Swiss National Park. The tendency is to even increase the area and intensify the use of ski pistes.

Ski pistes can be example systems for snow climate change in the Alps. Climate models vary considerably especially regarding precipitation in a changing climate (IPCC, 2001). Climate change can result in less snow and changed snow properties due to warming but also in enhanced snow fall at high altitudes due to increased precipitation. Thus, we can obtain valuable information from artificial changes in snow cover, be it in experimental approaches or on ski pistes, about possible ecological changes in a changing climate.

\section{Acknowledgments}

This study was financed by the Swiss Agency for the Environment, Forests and Landscape (SAEFL, Switzerland) and the cantons of Grisons and Valais. Johannes Rubbel, Sonja Wipf, and Kathy Schudel helped with the field work, and Andy Stoffel made the map of the snow distribution in Switzerland. We thank Catherine Mittaz, Martin Hölzle, Marcia Phillips, Martina Lütschg, and Bernhard Schmid for valuable discussions on the manuscript.

\section{References Cited}

Abegg, B., Koenig, U., Buerki, R., and Elsasser, H., 1997: Climate Impact Assessment im Tourismus. Die Erde, 128: 105-116.

Andrews, T., 1886: Observations of pure ice and snow. Proceedings of the Royal Society London, 40: 544-549.

Auerbach, N. A. and Halfpenny, J. C., 1991: Snowpack and the subnivean environment for different aspects of an open meadow in Jackson Hole, Wyoming, USA. Arctic and Alpine Research, 23: $41-44$.

Baiderin, V. V., 1982: Winter recreation and subnivial plant development. Soviet Journal of Ecology, 13: 287-291.

Bayfield, N. G., 1996: Long-term changes in colonization of bulldozed ski pistes at Cairn Gorm, Scotland. Journal of Applied Ecology, 33: 1359-1365. 
Bell, K. L. and Bliss, L. C., 1979: Autecology of Kobresia Bellardii: Why winter snow accumulation limits local distribution. Ecological Monographs, 49: 377-402.

Brooks, P. D., Williams, M. W., and Schmidt, S. K., 1996: Microbial activity under alpine snowpacks, Niwot Ridge, Colorado. Biogeochemistry, 32: 93-113.

Bürki, R., 1998: Klimaaenderung und Skitourismus: Wie wirkt sich eine Klimaaenderung auf die skitouristische Nachfrage aus? Geographica Helvetica, 53: 155-161.

Cernusca, A., Angerer, H., Newesely, C., and Tappeiner, U., 1990: Ökologische Auswirkungen von Kunstschnee: eine Kausalanalyse der Belastungsfaktoren. Verhandlungen der Gesellschaft für Ökologie, 19: 746-757.

Edwards, A. C. and Cresser, M. S., 1992: Freezing and its effect on chemical and biological properties of soil. Advances in Soil Science, 18: 59-95.

Ellenberg, H., 1988: Vegetation Ecology of Central Europe. 4th ed. Cambridge: Cambridge University Press. 731 pp.

Elsasser, H. and Messerli, P., 2001: The vulnerability of the snow industry in the Swiss Alps. Mountain Research and Development 21: 335-339.

Fattorini, M., 2001: Establishment of transplants on machine-graded ski runs above timberline in the Swiss Alps. Restoration Ecology, 9: 119-126.

Freppaz, M., Lunardi, S., Bonifacio, E., Scalenghe, R., and Zanini, E., 2002: Ski slopes and stability of soil aggregates. In Pagliai, M. and Jones, R. (eds.), Advances in GeoEcology 35: Sustainable Land Management-Environmental Protection. A Soil Physical Approach Catena, 125-132.

Funk, M. and Hoelzle, M., 1992: A model of potential direct solar radiation for investigating occurrences of mountain permafrost Permafrost and Periglacial Processes, 3: 139-142.

Galen, C. and Stanton, M. L., 1995: Responses of snowbed plant species to changes in growing-season length. Ecology, 76: 1546-1557.

Goodrich, L. E., 1982: The influence of the snow cover on the ground thermal regime. Canadian Geotechnical Journal, 19: 421-432.

Grabherr, G., 1985: Damage to vegetation by recreation in the Austrian and German Alps. In Bayfield, N. and Barrow, G. C. (eds.), The Ecological Impacts of Outdoor Recreation on Mountain Areas in Europe and North America. Asford (England): Recreation Ecol. Research Group Report, Wye College.

Green, B. F. and Tukey, J. W., 1960: Complex analyses of variance: general problems. Psychmetrika, 25: 127-152.

Groffman, P. M., Driscoll, C. T., Fahey, T. J., Hardy, J. P., Fitzhugh, R. D., and Tierney, G. L., 2001: Effects of mild winter freezing on soil nitrogen and carbon dynamics in a northern hardwood forest Biogeochemistry, 56: 191-213.

Haeberli, W., 1973: Die Basistemperatur der winterlichen Schneedecke als möglicher Indikator für die Verbreitung von Permafrost in den Alpen. Zeitschrift für Gletscherkunde und Glazialgeologie, 9: 221-227.

Haeberli, W., 1975: Untersuchungen zur Verbreitung von Permafrost zwischen Flüelapass und Piz Grialetsch (Graubünden). Mitteilungen der Versuchsanstalt für Wasserbau, Hydrologie und Glaziologie (VAW) der Eidgenössischen Technischen Hochschule Zürich, 17: $1-221$.

Haeberli, W., 1982: Skipisten im alpinen Permafrost. Materialien zur Physiogeographie, Basel, 4: 59-61.

Haeberli, W., 1992: Construction, environmental problems and natural hazards in periglacial mountain belts. Permafrost and Periglacial Processes, 3: 111-124.

Hardy, J. P., Groffman, P. M., Fitzhugh, R. D., Henry, K. S., Welman, A. T., Demers, J. D., Fahey, T. J., Driscoll, C. T., Tierney, G. L., and Nolan, S., 2001: Snow depth manipulation and its influence on soil frost and water dynamics in a northern hardwood forest. Biogeochemistry, 56: 151-174.

Hinkel, K. M., Bockheim, J. G., Peterson, K. M., and Norton, D. W., 2003: Impact of snow fence construction on tundra soil temperatures at Barrow, Alaska. Proceedings of the Eighth International Conference on Permafrost, vol.1, 401-405.

Hoelzle, M., Wegmann, M., and Krummenacher, B., 1999: Miniature temperature dataloggers for mapping and monitoring of permafrost in high mountain areas: first experience from the Swiss Alps. Permafrost and Periglacial Processes, 10: 113-124.

Horner, R. A., 1990: Techniques for sampling sea-ice algae. In Medlin, L. K. and Priddle, J. (eds.), Polar marine diatoms. Cambridge, England: British Antarctic Survey, 19-23.

IPCC, 2001: Climate Change 2001: Impacts, Adaptation \& Vulnerability. Contribution of Working Group II to the Third Assessment Report of the Intergovernmental Panel on Climate Change (IPCC). Cambridge: Cambridge University Press. 1000 pp.

Jones, H. G., Pomeroy, J. W., Walker, D. A., and Hoham, R. W., 2001: Snow ecology. Cambridge University Press: Press Syndicate of the University of Cambridge, $378 \mathrm{pp}$.

Kammer, P. M., 2002: Floristic changes in subalpine grasslands after 22 years of artificial snowing. Journal for Nature Conservation, 10: $109-123$.

Keller, F. and Gubler, H., 1993: Interaction between snow cover and high mountain permafrost, Murtèl/Corvatsch, Swiss Alps. In: Proceedings of the Sixth International Conference on Permafrost, Beijing, July 5-9, 1993. Guangzhou, China: South China University of Technology Press. Vol. 1: 332-337.

Keller, F. and Tamás, M., 2003: Enhanced ground cooling in periods with thin snow cover in the Swiss National Park. In Phillips, M., Springman, S. M., and Arenson, L. U. (eds.), Proceedings of the Eighth International Conference on Permafrost, Zurich, Switzerland, July 21-25, 2003, Vol. 1: 531-536.

Kocak, R. and van Gemert, H., 1988: Man-made snow: biotechnology assisting the skiing industry. Australian Journal of Biotechnology, 2: $37-38$.

Kokelj, S. V. and Lewkowicz, A. G., 1998: Long-term influence of active-layer detachment sliding on permafrost slope hydrology, Hot Weather Creek, Ellesmere Island, Canada. In Lewkowicz, A. G. and Allard, M. (eds.), Seventh International Conference on Permafrost, Yellowknife, Northwest Territories, June 23-27, 1998. Sainte Foy, Québec: Université Laval. Collection Nordiciana 57: 583-589.

Körner, C., 1999: Alpine Plant Life. Berlin: Springer-Verlag. 338 pp.

Krummenacher, B., Budmider, K., Mihajlovic, D., and Blank, B., 1998: Periglaziale Prozesse und Formen im Furggentälti, Gemmipass. Mitteilungen des Eidgenössischen Institutes für Schnee- und Lawinenforschung, Davos, 56: 1-245.

Larcher, W., 1995: Physiological Plant Ecology. 3rd ed. Berlin, Heidelberg: Springer-Verlag. 506 pp.

Lipson, D. A. and Monson, R. K., 1998: Plant-microbe competition for soil amino acids in the alpine tundra: effects of freeze-thaw and dryrewet events. Oecologia, 113: 406-414.

Mackay, J. R. and MacKay, D. K., 1975: Snow cover and ground temperatures, Garry Island, N.W.T. Arctic, 27: 287-296.

May, D. E., Webber, P. J., and May, T. A., 1982: Success of transplanted alpine tundra plants on Niwot Ridge, Colorado. Journal of Applied Ecology, 19: 965-976.

Mellini, K., 1996: Skipisten und Permafrost - Untersuchungen der Permafrostverbreitung auf der Diavolezza unter besonderer Berücksichtigung der Einwirkung von Pistenpräparation und Pistenbeschneiung auf die Bodentemperatur. Masters Thesis, Geografisches Institut der Universität Zürich, Universität Zürich. 113 pp.

Mittaz, C., Hoelzle, M., and Haeberli, W., 2000: First results and interpretation of energy-flux measurements over Alpine permafrost. Annals of Glaciology, 31: 275-280.

Mosimann, T., 1985: Geo-ecological impacts of ski piste construction in the Swiss Alps. Applied Geography, 5: 29-37.

Mosimann, T., 1987: Schneeanlagen in der Schweiz, aktueller Stand Umwelteinflüsse - Empfehlungen. Materialien zur Physiogeographie, 10: 112.

Neilson, C. B., Groffman, P. M., Hamburg, S. P., Driscoll, C. T., Fahey, T. J., and Hardy, J. P., 2001: Freezing effects on carbon and nitrogen cycling in northern hardwood forest soils. Soil Science Society of America Journal, 65: 1723-1730. 
Newesely, C., Cernusca, A., and Bodner, M., 1994: Entstehung und Auswirkung von Sauerstoffmangel im Bereich unterschiedlich präparierter Schipisten. Verhandlungen der Gesellschaft für Ökologie, 23: 277-282.

Newesely, C., 1997: Auswirkungen der künstlichen Beschneiung von Schipisten auf Aufbau, Struktur und Gasdurchlässigkeit der Schneedecke, sowie auf den Verlauf der Bodentemperatur und das Auftreten von Bodenfrost. Dissertation, Naturwissenschaftliche Fakultät, Leopold Franzens Universität, Innsbruck. 239 pp.

Pomeroy, J. W. and Brun, E., 2001: Physical properties of snow. In Jones, H. G., Pomeroy, J. W., Walker, D. A., and Hoham, R. W. (eds.), Snow Ecology. Cambridge: Cambridge University Press, 45-126.

Price, M. F., 1985: Impact of recreational activities on alpine vegetation in western North America. Mountain Research and Development, 5: 263-277.

Recco Rescue Systems, 1999: Directions for Use and Training. Lidingö, Sweden.

Rixen, C., Stoeckli, V., Huovinen, C., and Huovinen, K., 2001: The phenology of four subalpine herbs in relation to snow cover characteristics. Proceedings of the Sixth IAHS Symposium 2001. Soil-Vegetation-Atmosphere Transfer Schemes and Large Scale Hydrological Models. IAHS Publication 270: 359-362.

Rixen, C., 2002: Artificial snow and snow additives on ski pistes: interactions between snow cover, soil and vegetation. $\mathrm{PhD}$ thesis, Institute for Environmental Sciences, University of Zurich. 162 pp.

Rixen, C., Stoeckli, V., and Ammann, W., 2002: Does artificial snow production affect soil and vegetation of ski pistes? A review. Perspectives in Plant Ecology, Evolution and Systematics, 5: 219-230.

Rixen, C., Casteller, A., Schweingruber, F. H., and Stoeckli, V., 2004: Age analysis helps to estimate plant performance on ski pistes. Botanica Helvetica, 114: 127-138.

Seppäla, M., 2003: An experimental climate change study of the effect of increased snow cover on active layer formation of a palsa, Finnish Lapland. Proceedings of the Eighth International Conference on Permafrost, Zurich, Switzerland, July 21-25, 2003, Vol. 1: 1013-1016.

Schimel, J. P., Bilbrough, C., and Welker, J. A., 2004: Increased snow depth affects microbial activity and nitrogen mineralization in two Arctic tundra communities. Soil Biology \& Biochemistry, 36: 217-227.

Seilbahnen Schweiz, 2001: Wirtschaftsbericht 2001. Paul Haupt AG, Bern.

Sommerfeld, R. A., Mosier, A. R., and Musselman, R. C., 1993: CO2, $\mathrm{CH} 4$ and $\mathrm{N} 2 \mathrm{O}$ flux through a Wyoming snowpack and implications for global budgets. Nature, 361: 140-142.

SPSS, 1999: SPSS for Windows. SPSS Inc., Chicago.
Stoeckli, V. and Rixen, C., 2000: Characteristics of artificial snow and its effect on vegetation. Conference Proceedings of the International Snow Science Workshop: 468-471.

Sturm, M., Holmgren, J., König, M., and Morris, K., 1997: The thermal conductivity of seasonal snow. Journal of Glaciology, 43: $26-41$.

Sulkava, P. and Huhta, V., 2003: Effects of hard frost and freeze-thaw cycles on decomposer communities and $\mathrm{N}$ mineralisation in boreal forest soil. Applied Soil Ecology, 22: 225-239.

Tierney, G. L., Fahey, T. J., Groffman, P. M., Hardy, J. P., Fitzhugh, R. D., and Driscoll, C. T., 2001: Soil freezing alters fine root dynamics in a northern hardwood forest. Biogeochemistry, 56: 175190.

Titus, J. H. and Tsuyuzaki, S., 1999: Ski slope vegetation of Mount Hood, Oregon, U.S.A. Arctic, Antarctic, and Alpine Research, 31: 283-292.

Tsuyuzaki, S., 1995: Ski slope vegetation in Central Honshu, Japan. Environmental Management, 19: 773-777.

Urbanska, K. M., 1990: Ecologically compatible revegetation of highalpine ski runs. Zeitschrift für Vegetationstechnik, 13: 74-83.

Urbanska, K. M., 1995: Biodiversity assessment in ecological restoration above the timberline. Biodiversity and Conservation, 4: 679-695.

Urbanska, K. M., 1997: Restoration ecology research above the timberline: Colonization of safety islands on a machine-graded alpine ski run. Biodiversity and Conservation, 6: 1655-1670.

Walker, M. D., Walker, D. A., Welker, J. M., Arft, A. M., Bordsley, T., Brooks, P. D., Fahnstick, J. T., Jones, M. H., Losleben, M., Davsons, A. N., Seastedt, T. R., and Turner, P. L., 1999: Long-term experimental manipulation of winter snow regime and summer temperature in arctic and alpine tundra. Hydrological Processes, 13: 2315-2330.

Weih, M. and Karlsson, P. S., 2002: Low winter soil temperature affects summertime nutrient uptake capacity and growth rate of mountain birch seedlings in the Subarctic, Swedish Lapland. Arctic, Antarctic, and Alpine Research, 34: 434-439.

Williams, M. W., Brooks, P. D., and Seastedt, T., 1998: Nitrogen and carbon soil dynamics in response to climate change in a highelevation ecosystem in the Rocky Mountains, U.S.A. Arctic, Antarctic, and Alpine Research, 30: 26-30.

Wipf, S., Rixen, C., Fischer, M., Schmid, B., and Stoeckli, V. (in press): Effects of ski piste preparation on alpine vegetation. Journal of Applied Ecology.

Ms submitted December 2002 Revised ms submitted March 2004 